\title{
On Contrasts in the Charcoal Assemblage of a Late Iron Age and Romano-British Roadside Settlement
}

\section{Comparación entre el registro antracológico de las ocupaciones de la Edad del Hierro Final y del período romano-britano en un yacimiento junto a una vía}

\section{JONATHAN ADAM BAINES}

Dpt. of Post Excavation. Northern Archaeological Associates. jojobaines@gmail.com

\begin{abstract}
:
This article examines the similarities and differences in the charcoal assemblage recovered from indigenous (pre-contact) roadside settlements, the Roman arrival and their subsequent occupation of the region. Samples taken from various archaeological features which form part of the surrounding system of strip fields, structures bordering a road junction, an industrial quarter and a vicus are investigated for remnants of fuel, craft and construction. Temporal and spatial changes in composition are interpreted as the result of pressure on firewood supply due to settlement developments and reorganisation. The recovered charcoal assemblage is mostly the product of deposition of those taxa that are most numerous on site - due to their usefulness as fuel or in construction. The distinct proportion of less common taxa in mature stands - lime, elm and maple - evince opportunistic foraging of fuel from beyond the usual firewood collection range as well as local manufacture of tools and use in carpentry.
\end{abstract}

Key words: anthracology, Roman Britain, wood exploitation, roadside settlement.

\section{RESUMEN:}

En este artículo se analizan las similitudes y diferencias en el registro antracológico entre los niveles indígenas (pre-contacto) y aquellos resultantes a partir de la presencia romana en un yacimiento situado junto a una vía de comunicación. Las muestras, vinculadas a su uso como combustible, trabajos artesanales y constructivos, se han tomado de diferentes espacios arqueológicos, que formaban parte del sistema de campos circundantes, de las estructuras que limitaban el cruce de caminos, de un área industrial y de un vicus. Los cambios espaciales y temporales identificados en el registro se interpretan en relación a la presión para la obtención de leña, provocada por el desarrollo del asentamiento y su reorganización. El conjunto de carbones recuperado es resultado, mayoritariamente, de la deposición de aquellos taxa más abundantes debido a su uso como leña y en la construcción. La distinta proporción de aquellos taxa menos comunes -tilo, olmo y arceevidencian prácticas oportunísticas de obtención de leña, así como su uso para la fabricación de utensilios y en labores de carpintería.

Palabras clave: antracología, Britania romana, explotación de madera, asentamiento junto a una vía. 


\section{INTRODUCTION}

During the A1 motorway widening scheme between Leeming and Barton, north-eastern England, in 20142017, archaeological excavations revealed various Late Iron Age and Romano-British roadside settlements (Speed and Holst 2019; Fell 2019; Ross and Ross forthcoming). Subsequent investigation of the sediment samples by the author at Northern Archaeological Associates revealed a substantial and varied charcoal assemblage. Although over 2652 contexts, from this $18 \mathrm{~km}$ long transect, were examined, this article presents a synopsis of the data to discuss what wood people exploited during the transition from the native Late Iron Age to the Romanised era.

Though trade across the North Sea had connected Britain to the Roman world prior to Julius Caesar's excursions in 55 and 54 BC, cultural, floral and faunal import gained momentum after the invasion under Claudius in $43 \mathrm{AD}$. The Roman army quickly consolidated their foothold in the SE and established the first governorship of their new province: Britannia; that same year. However, despite diplomatic missions and the establishment of client kingdoms (Fell 2019) insurgency plagued the spread of influence and control northwards throughout the 50s and 60s AD. Not until repeated rebellions among the Brigantes - the principal tribe in northern England at the time - were successfully put down in the 70s did governor Agricola's campaign bring calm to the region in the early 80s. Whilst these four decades constituted intermittent phases of concord, conquest and consolidation, the preceding century of low level exchange may be termed pre-contact (Fell 2019) and the succeeding three centuries as membership in an empire watched over by large garrisons of auxiliaries and officials from the governor's office.

Numerous contexts will be collated to obtain a distinct and comparable unit for contrasting the record from outlying strip field systems that backed onto a road, a settlement core at a road junction and a transect of a vicus by a bridge. By examining these three types of roadside occupation, we can additionally compare the impact of their different settlement character on the exploitation of wood. One group contains remains from farmsteads in a structured land arrangement on the quasi rural periphery of a central community. The second group covers the development of said community into a semi-urban village. The third group collates various structures and archaeological features within an urban centre. Tentatively these distinctions could be taken one step further and differentiate between the class of people living at these locales according to their disposal of spent fuel and from refurbishment of their buildings and roofing.

Despite the slight differences in the effort and travel range for the urban inhabitants, those living on the periphery or on roadside farmsteads to acquire their wood, the tree cover across this research area was comparable. Ample riparian woodlands were within a kilometre of the sites along becks or the river Swale. Clay and loamy freely draining soils as well as riverine gravel terraces provided various habitats interspersed by fertile arable fields and meadows. Though hypothetical, the climate was slightly warmer and moister in the late 1st century BC, 1st and 2nd centuries AD than afterwards (McCormick et al. 2012). Peculiarities in the charcoal assemblage recovered from the three settings are therefore more probably related to human circumstance or choice than constraints in, or derived from, their similar environment.

Though another distinction in the character of the sites could be noted in the presence and absence of the Roman military, their impact on the exploitation of wood and deposition/preservation of charcoal fragments can not be tested per se. Whilst the charcoal record representing the pre-contact era forms a point of comparison with the later period of occupation and military administration, this settlement phase was neither exclusively civil nor military. Thus, the impact of this foreign presence on the charcoal assemblage of the later roadside settlements stems from both. Whilst Romanisation of the indigenous population in the frontier provinces may be interpreted as assimilation or enforced integration for the purpose of display, gaining political influence, or establishing a trade network, it is hard to trace this in charcoal. Though the ecofacts of environmental archaeology - bones, seeds, charcoal, starches, phytoliths etc. - can be taken as objects to portray either the implementation of new farming ideas and culinary traditions, or their rejection, they are unlike foreign structure designs and artefacts that inherently demonstrate acculturation (van der Veen 2016a). What, for instance, would distinguish indigenous from Romanised firewood collection? The native British did not live in the upland fringes and inhospitable North alone; they were the province; the villas and the native aristocracy were the diffuse margins of society. In focussing on the latter sites, perhaps, a charcoal assemblage could reveal signs of deviancy from native customs and thereby highlight imports. However, these sites were not as busy as a roadside settlement 
Fig. 1: Location of Scotch Corner, Cataractonium and the Bainesse roadside settlement. Adapted from Damien Ronan, NAA.

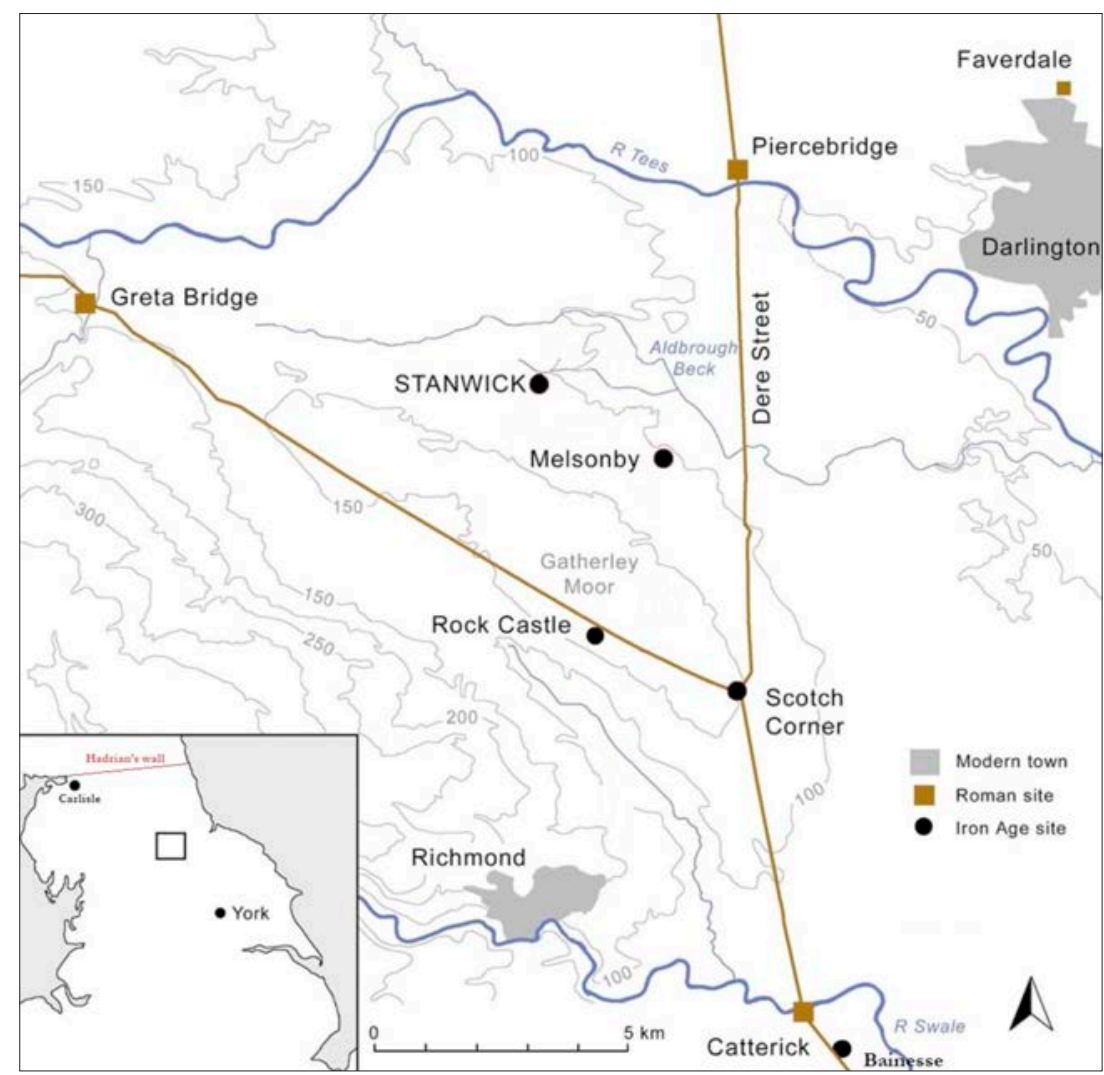

(Monckton 2011; Rackham et al. 2013). By transecting a community in which the military, local elite, labourers and peasants passed each other the record becomes mixed. After post-depositional activity truncated the record only the most frequently charred taxa were preserved. A particular taxon may stand out or a distinct change in spatial and temporal proportion may be recognised but no longer whether they were due to urbanity, nor romanisation.

Not only do the charcoal fragments disengage the studied samples from any implications of Romanisation, but also from the distinction between a military or civil character. This article therefore discusses what the recovered wood remains from particular settlement phases and locations tell about human activities there, or at least in the vicinity.

\section{REGIONAL SETTING}

The dataset examined in this article was selected from a larger programme of archaeological excavations conducted by NAA ltd. for Highways England and arbitrarily divided into three settings: pre-contact at Scotch Corner, the Roman occupation of Scotch Corner and the Roman period at Cataractonium (Catterick) and Bainesse (see fig. 1). In order to approach its research question: what wood did people exploit during the Late Iron Age and Roman period? each setting covers a distinct character of roadside settlement and land usage in overlapping dates that range from the Late Iron Age, through the decennia of conquest and occupation until the Romans abandoned Britannia in the Early 5th Century AD.

The three settings are on the same routeway: in the Late Iron Age (1st Century BC to mid-1st Century AD) it was a major $\mathrm{N}-\mathrm{S}$ artery through the lands of the Brigantes, subsequently a logistic jumping board for the Roman army's pacification of the north (50s to $80 \mathrm{~s}$ AD) and later the strategically significant link - known as Dere Street - between Hadrian's wall and Eboracum (York). On the fork of this trunk road, and the way across the Pennine hills (only approximately $400 \mathrm{~m}$ a.s.1., but very exposed terrain) towards Luguvalium (Carlisle) and the western coastline, was the road junction settlement at Scotch Corner (Zant 2013). The fertile land between the Rivers Tees 
and Swale was populous and numerous coeval sites have been identified or excavated (Haselgrove and Moore 2016). The Brigantes centre at Stanwick (van der Veen 2016b), Melsonby (Fitts 1999), Rock Castle (Fitts et al. 1994), Faverdale (Akeret et al. 2007) and the various enclosures along the modern A66 between Greta Bridge and Scotch Corner (Huntley 1995; Challinor and Druce 2013) are some examples with a comparable charcoal record. Dere Street grew into an important artery during the Roman occupation with numerous defended bridges where forts were constructed and prosperous vici developed - that are comparable to the site at Cataractonium on the river Swale. Piercebridge on the river Tees (Harding 2008) and Binchester on the River Wear (Ferris 2010) for example are $16 \mathrm{~km}$ and $36 \mathrm{~km}$ respectively to the $\mathrm{N}$, but more significantly with a comprehensive charcoal report is Healam Bridge $20 \mathrm{~km}$ to the $\mathrm{S}$ on the Healam beck (Jaques et al. 2017).

\section{METHODS AND DATASET}

The assemblage was recovered through flotation - following the Siraf method (Williams 1973) - at NAA Ltd. of all the sediment samples and subsequent picking out of the charcoal fragments from the $0,5 \mathrm{~mm}$ mesh according to Historic England guidelines (Campbell et al. 2011). A physical reference collection and wood anatomy guides (Schweingruber 1990; Hather 2000) were consulted for all taxa identifications made by the author. Note that in those cases where the wood anatomy of particular genera could not be definitely distinguished, both options are recorded in alphabetical order. Instead of counting the number of fragments of each taxon in the sample, approximate proportions and total weight were noted (Moskal-del Hoyo 2011). The volume of sediment of each sample, standard 40 litres or $100 \%$ of a feature if less volume was available, was recorded and allows the calculation of find densities per phase and archaeological context. No contexts were sub-sampled. The data presented in this article is always the number of contexts that a taxon occurred in (not weight or number of fragments) in an investigated area or period proportionate to the number of examined contexts. All context descriptions and the allocation of their relative date (phasing) was prepared by the field archaeologists and senior project officers (Fell 2019; Ross and Ross forthcoming). Whilst the spatial and temporal comparisons discussed here are based on arbitrary grouping of similar archaeological features within distinct settlement phases, a particular large spread of burnt material, the result of a 3rd Century town fire, - and later cleared during the Severan refortification and further development of the vicus into a town - was sampled in $1 \mathrm{~m}$ square grid fashion to facilitate spatial comparison of the sample composition. This is the only clear fire event in the assemblage where the recovered charcoal fragments had burnt in situ. Whilst this may also be the case for those fragments retrieved from features interpreted as kilns, ovens or hearths, and will therefore be mentioned in the discussion sections, in all other cases the charcoal was presumably deposited, and did not burn in situ.

Besides the abundance of undetermined hardwood, softwood and roundwood fragments, 27 taxa were identified. Though only one represents imported wood for certain: silver fir (Abies alba), presumably from barrel staves or construction wood, four species were not native to the region and were more likely part of an object, than merely spent firewood (Huntley 2010). Whilst wayfaring trees (Viburnum lantana), hornbeam (Carpinus betulus) and beech (Fagus sylvatica) were native to the Southern half of Britain, they probably were not common in Northern forests. Conversely, whilst the Scots Pine (Pinus sylvestris) inhabited the distant North, it was not yet part of English woodlands. Though the fragment of walnut wood (Juglans regia), recovered from the sunken floor of a Severan (late 2nd to mid-3rd Century AD) structure inside the Romanized vicus of Cataractonium, was a shaped remnant of undetermined furniture, it is unsure whether this species was already planted in the region by the $3 \mathrm{rd}$ Century $\mathrm{AD}$, or at all in Britannia for that matter, or brought from the continent.

Amongst the other 22 taxa there were some species that are rarer members of the wild tree cover: European spindle (Euonymus europaeus), lime (Tilia cordata) and wych elm (Ulmus glabra). A variation in wood exploitation was observed in the various archaeological contexts: enclosure ditches, drip gullies, pits, postholes or hearths, across the different settlement phases. Despite opportunistic firewood collection being the norm and the high potential for redeposition, some contrasts could indicate a particular wood usage as kindling, timber, roofing or in the construction of hurdles and wattle walls (Shackleton and Prins 1992).

The fact that the plant specimens preserved in a charred state implies some human agency in their deposition (van der Veen 2007). Despite some in situ preservation or 
Fig. 2: Proportionate occurrence of the principal taxa in the roadside settlement and the industrial quarter.

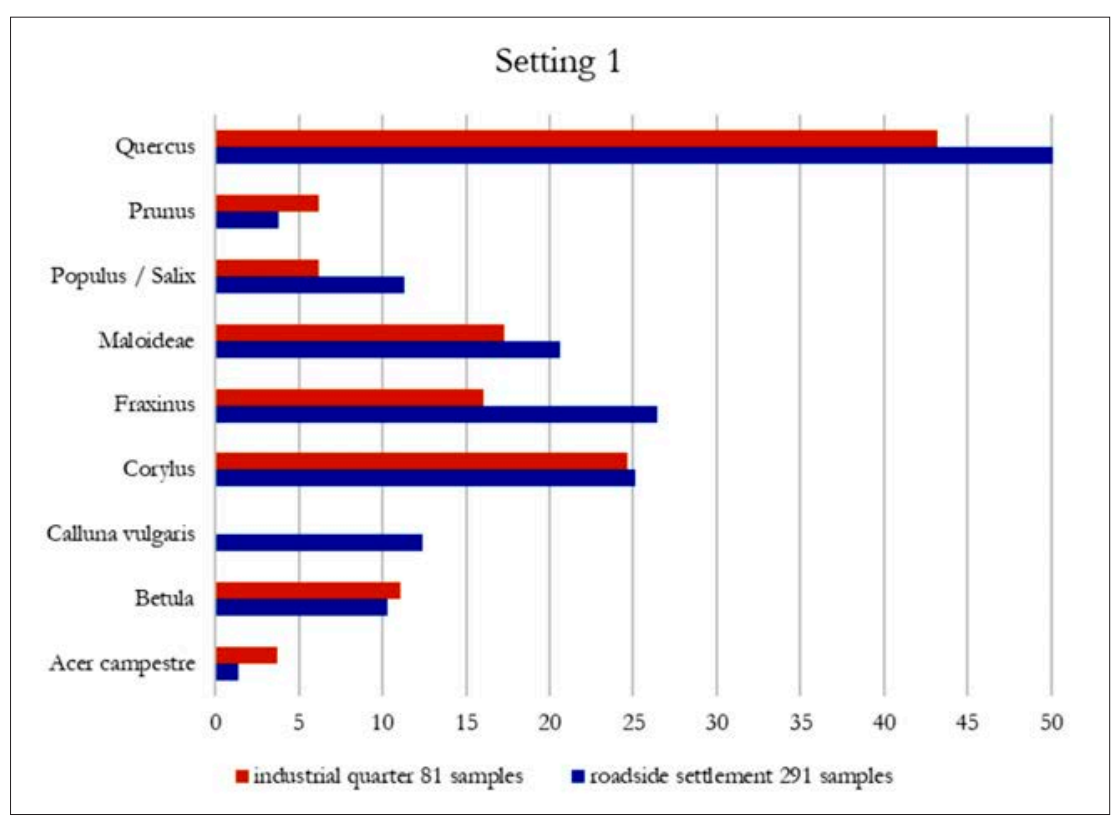

sealing by other archaeological layers, varied circumstances will have led to redeposition and mixing of the charcoal fragments or inadvertent destruction. In sum, those taxa that were most copious will have a higher potential of archaeobotanic recovery (Jones 1991). However, does ubiquity imply abundance nearby, or did human agency preferentially impact the deposition of particular taxa? The ubiquity in oak for instance is presumably due to its use in construction and as excellent firewood.

Because a substantial portion of the assemblage was residual - or redeposited - and has no discrete temporal, spatial, nor cultural or functional context, only in those instances where a concrete interpretation is made, with regards to the archaeological feature or the recovered taxa, will further detail of its archaeological context be provided.

The first setting is a transect across about 700 metres of enclosure ditches, with associated pits, postholes, gullies and debris from various roadside activities at Scotch Corner. The whole is commonly categorised as a system of strip fields, whereby each plot has a narrow front facing a trackway - in this case a precursor of Dere Street (Harding 2004). Alternatively, it may be interpreted as a comb-shaped enclosure system (sensu Wieringa 1958) that stretched widely across the region's rich farm land. Although this Iron Age agricultural system was mostly based on subsistence farming, one may presume some surplus production across such a vast agglomeration of comb-shaped enclosures to provide for an elite and craftspeople. Whilst they lived in a community of roundhouses with minimal enclosure, excavation revealed a continuously changing configuration of enclosure around the plots which suggests animals were kept nearby and a particular sense of ownership or demarcation (Armit 2006). Presumably these rearrangements also indicate a degree of change in land use within a long-lived tradition of agricultural practice (Brindle 2016). This setting covers the Late Iron Age community throughout the 1st Century BC until Roman influence following the conquest reaches the region in the late 50's AD. The junction and settlement concentration probably grew in this particular location because of the rich limestone and copper deposits there. Artisans and other craftspeople had worked these resources since the late 1st Century BC but had mostly quit by the late 60 's AD. Although such craftwork likely demanded a supply of wood distinct from the everyday needs of subsistence farmers (see fig. 2), because residual charcoal from the roadside settlement and adjoining comb-shaped enclosures mixed in with the spent fuel and workshop debris, the pre-contact samples are included in this first setting.

The less common taxa in the roadside settlement are heather (Calluna vulgaris), hornbeam, european spindle, rose (Rosa sp.), yew (Taxus baccata), silver fir, lime, wych elm, alder (Alnus glutinosa) guelder-rose (Viburnum opulus) and dogwood (Cornus sanguinea). Whilst 
the industrial quarter also preserved alder, guelder-rose and dogwood charcoal, alder buckthorn (Frangula alnus) fragments were exclusively found there.

Though the second setting overlaps in date at the start - from the final, pre-contact, Iron Age through the era of concord as a client kingdom and occupation to the Nervan near abandonment in the late 90's AD - its settlement character is considerably different. Instead of stretching out along the two main axes, it becomes more concentrated on the junction. At the hub of various important routeways in a populous region of fertile farmland and mature woodlands, this particular location featured prominently in the Roman military's understanding of control, logistics and offense. Both routes quickly became formalised as trunk roads for commerce and the army. Despite the lack of a garrison, although there are plenty of marching camps in the vicinity, Scotch Corner presumably hosted high military and civil officials (Bishop 2005). The presence of metalworking artisans and other craftspeople had probably elevated the site above the customary huddle of farmsteads and further drew Roman officials' attention to the area. Though they profoundly influenced the site for about two decades, before moving on towards the Picts, the environmental record mainly consists of the same plant and animal remains as before.

The third setting investigates eight facets of Cataractonium which lies 12 kilometres south of Scotch Corner. As the latter site waned, a fort and vicus were established during Agricola's governorship where the now formalised $\mathrm{N}-\mathrm{S}$ road crosses the river Swale. The vicus gradually grew throughout the late Flavian to Trajanic era and spread on the northern bank of the river. The settlement on both banks was enclosed by a ditch and earthen rampart during the mid-Antonine period (mid 2nd Century AD). Presumably the growth of Cataractonium, and its hinterland that stretched at least a mile southward towards Bainesse (Wilson 2002), is in part due to the Roman military's investment in the area and their presence until the late 3rd Century. However, whilst the civil character developed, the military presence was restricted to garrison duties performed by auxiliaries from Raetia and the Danube region (Cuff 2010). Though the diversity and proportion of taxa remained similar to the other settings, more silver fir fragments were identified. This presumably reflects the greater volume of barrels and implements brought over from the continent in a more long-lived urban setting. Cataractonium was further fortified in the $3 \mathrm{rd}$ Century, the town on the southern bank was enclosed with a formidable wall and a stone bridge was built. As the extramural settlement grew, timber buildings that fronted Dere Street and side streets inside the walled town were gradually renovated with stone.

One such moment of clearance and rebuilding preserved a large deposit of burnt debris from a mid-3rd century conflagration. Two distinct plots that had burnt down were uncovered during the excavations: an undetermined structure - here labelled as 23970 - and a house. Because the latter was meticulously excavated in $\mathrm{m}^{2}$ grid fashion and a clear outline of postholes was interpreted as a timber building (no tiles, bricks or daub remains were found), I was able to distinguish between an "inside" the building and an "outside" record (NAA forthcoming; Ross and Ross 2020).

Finally, the records of five 2nd to 4th Century enclosures near Dere Street at Bainesse and a cluster of late 4th Millennium BC Neolithic pits and gullies are inspected to test the dendrological interpretations. Whilst the latter certainly is a temporal outlier in the data set and provides a point of contrast for the local natural tree cover and the taxa collected as firewood, the former overlaps with the post conquest settlement of the road and enables comparison with the other data forthrightly. These roadside enclosures included samples from a similar array of domestic and structural features discussed before, yet due to their peripheral location presumably underwent less direct contact with the Roman military, but no less Romanising influences. Enclosure A contained a timber building and its backyard that fronted Dere Street. The other four were the back plots of those roadside houses. Enclosure $\mathrm{C}$ also included a timber building with a flagged floor and two wings that may represent a detached property of some standing. They present a temporally diffuse transect across what was an extensive ribbon of roadside urbanisation that stretched 1,5 km southwards from Cataractonium.

\section{RESULTS AND DISCUSSION}

\section{INDUSTRIAL QUARTER}

Not as precise or "closed" (sensu Jacomet 1989) as the conflagration debris, the record retrieved from the industrial quarter does enable some examination of the charcoal remains derived from a restricted set of activities. A higher proportion of field maple there, compared to the roadside settlement, for instance stands out which 
Fig. 3: Proportionate occurrence (frequency, by number of samples) of all taxa during the Roman era in the industrial quarter.

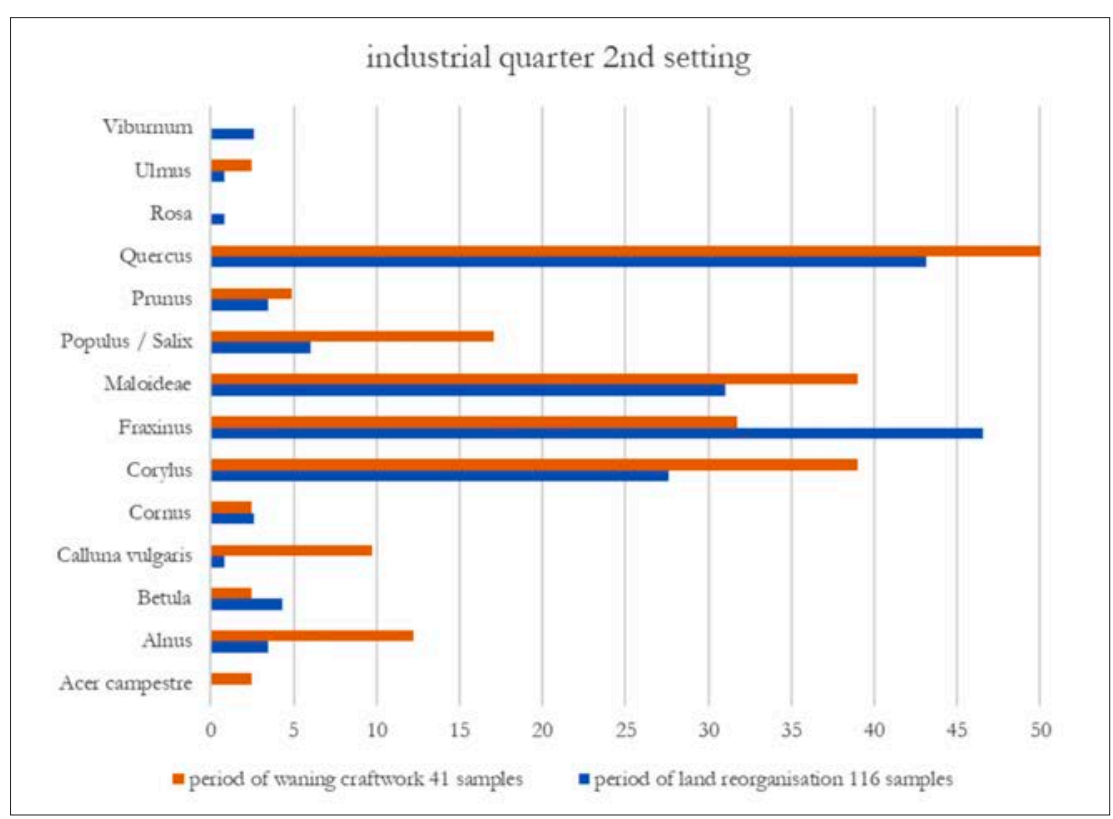

could suggest woodcarvers and carpenters made use of its fine grain in the manufacture of objects and furniture. Though craftwork decreased in the late 50's and 60's, field maple remains present (see fig. 3). Hypothetically, the abundance of high calorific fuel from shrubs (Prunus sp. and Maloideae) and maple indicates additional firewood was collected by pruning hedges, gathering deadwood and cutting back new growth from recently cleared land. Conspicuously, heather becomes abundant at the time of major disturbance in the area, but not before or afterwards. Likely the ubiquity of heather branches represents remains of demolition of old indigenous structures to make way for the road junction's overhaul. Mature heather stems for instance were used as thatch and in cladding wattle or hurdles and will have made excellent tinder.

After craftwork had ceased, the area was reorganised into rectilinearly enclosed plots similar to those 2 nd to 4th Century plots uncovered at Bainesse; possibly centuriation. Compared to earlier, the charcoal record becomes more homogenous and the proportion of shrubs drops. The surfeit of ash upon arrival of Roman influence at the roadside enclosures and junction (see fig. 4) was presumably greater than grew wild nearby and implies a managed supply that derived from circumstances in the settlement. Whether this boom in ash is linked to the arrival of Roman influence to the region, or developments in the settlement at Scotch Corner and the growth of the vicus beside the fort at Cataractonium (see fig. 5), is unsure, yet suggests a region-wide effort to supplement the exploitation of oak with ash. That the ratio of ash to oak did not drop during Scotch Corner's occupation (70's to late 90 's), at a time when the population no longer grew, nor did the community hold a distinct administrative or metalworking position and building stagnated, suggests the high proportion of ash was not in response to a greater need for fire and construction wood. Though oak was the primary carpentry wood, presumably a part of the ash surfeit during the vicus' establishment (70's to approximately 117) was the product of its use in joinery and construction. The rest however could be off-cuts or scraps from craftwork, or specially sourced firewood, to support the Roman Army. In sum, though the industrial quarter ceased during the Flavian occupation, some woodworking at Scotch Corner may be inferred from the oak and ash ratio.

\section{FLUCTUATIONS AND RATIOS}

As alluded to before, the change in ratio between oak and ash upon arrival of Roman influence to the region implies people supplemented their firewood and carpentry with ash, but this fluctuation does not mean the exploitation of oak dropped, just that more ash charcoal has been preserved compared to earlier. Whilst this peak in ash grows further into the Flavian occupation of Scotch 


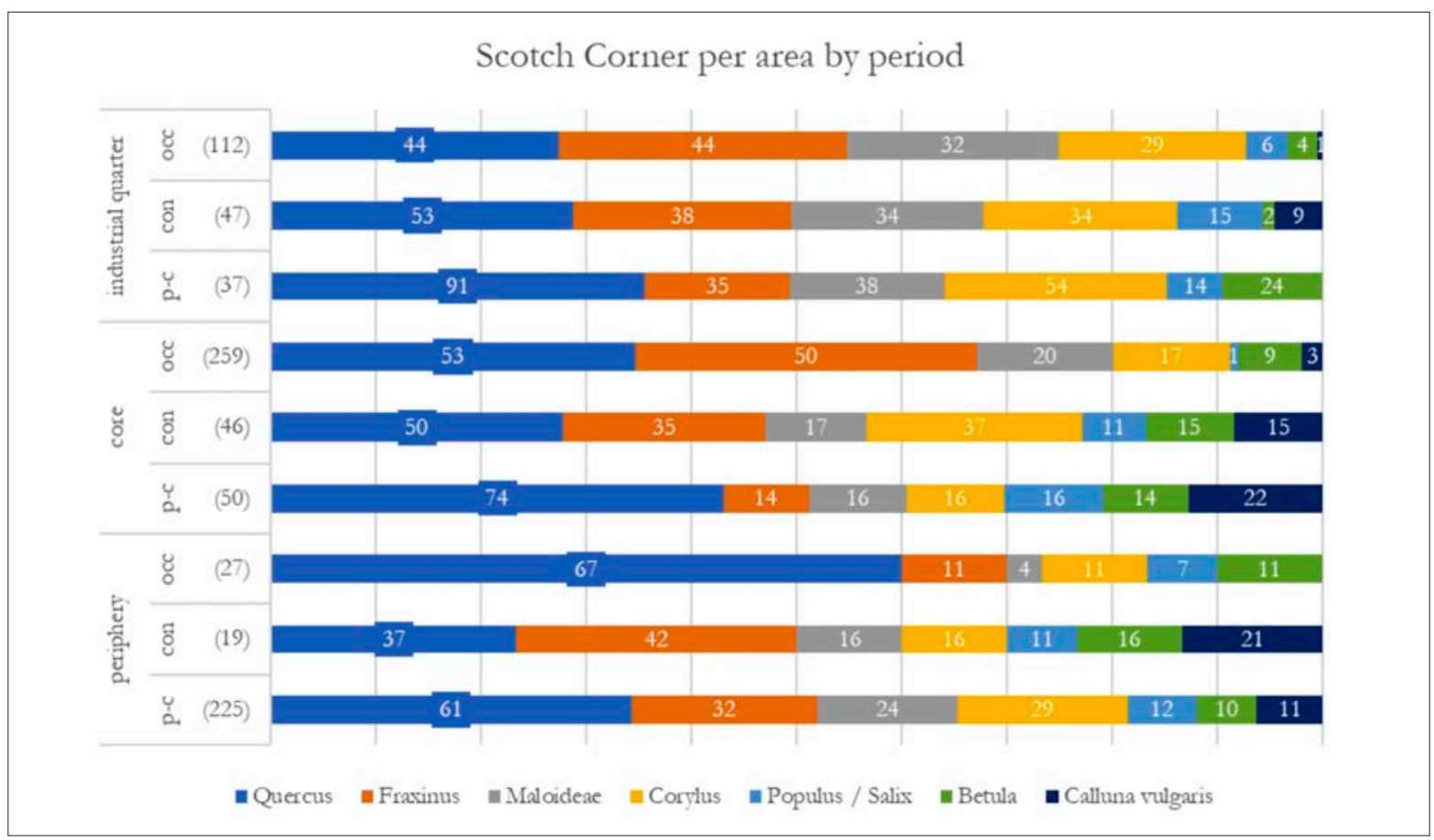

Fig. 4: Proportionate occurrence of the principal taxa per area of the whole settlement by relative period at Scotch Corner. $\mathrm{p}-\mathrm{c}=$ precontact (1st Century BC to 40s AD), con = conquest (50s and early 60s) and occ $=$ occupation (late $60 \mathrm{~s}$ to $90 \mathrm{~s} \mathrm{AD}$ ).

Corner, the smaller increase in hazel, poplar/willow and Maloideae is mostly restricted to the 50's and 60's. This temporal distinction suggests that whilst the North was tied, regardless of the intermittent hostility, into a client relationship with Rome, more wood from copses was burnt than before the arrival of Roman influence and during its decline in the $80 \mathrm{~s}$ AD. Though tentative, it implies that the Roman presence, more so in the era of relative concord (50s and 60s), but still noticeable in the proportion of ash under occupation in the 70s, affected wood procurement at Scotch Corner.

In dividing the assemblage from Scotch Corner, presented in fig. 4 into the three main areas: the roadside settlement periphery, the core around the junction and the industrial quarter, it becomes clear that these temporal trends have spatial distinctions. The ratio of ash and oak for instance inverts significantly in the periphery during the Flavian occupation, compared to the ratio in the settlement core and adjoining reorganised plots. Moreover, whilst the birch, hazel and poplar/willow proportions are similar, Maloideae also drops. Thus, if the charcoal record from the enclosures before contact embodies the normal mixture of waste from construction and spent fuel in farmsteads - principally oak and hazel (Zant 2013: $123)$, with the other taxa as minor additions from craftwork, kindling and opportunistic firewood collection then the altered ratios during 50's and 60's reflect the settlement-wide changes. Presumably the significantly different proportion of ash, oak and Maloideae during the Flavian occupation is a result of the gradual abandonment and altered land division of the strip fields. Whilst this affected the availability of deadwood from hedges or borders, the exploitation and supply of ash now centred around the road junction and the new plots alone. Because building and development stagnated in the periphery, people could burn oak which would otherwise have been restricted for construction purposes. Similarly, the high ratio of oak, and equal proportions of the other principal taxa at the pre-contact settlement of the junction reflects its stability and rural character. The pressure on oak for building, renovation and hypothetically the presence of the Roman army at the road junction from the 50's onwards reduced its proportion in the consumed firewood. Exploitation for fuel, and supplementary construction wood, shifted towards nearby copses of ash and hazel. Birch, heather and Maloideae tinder remained 


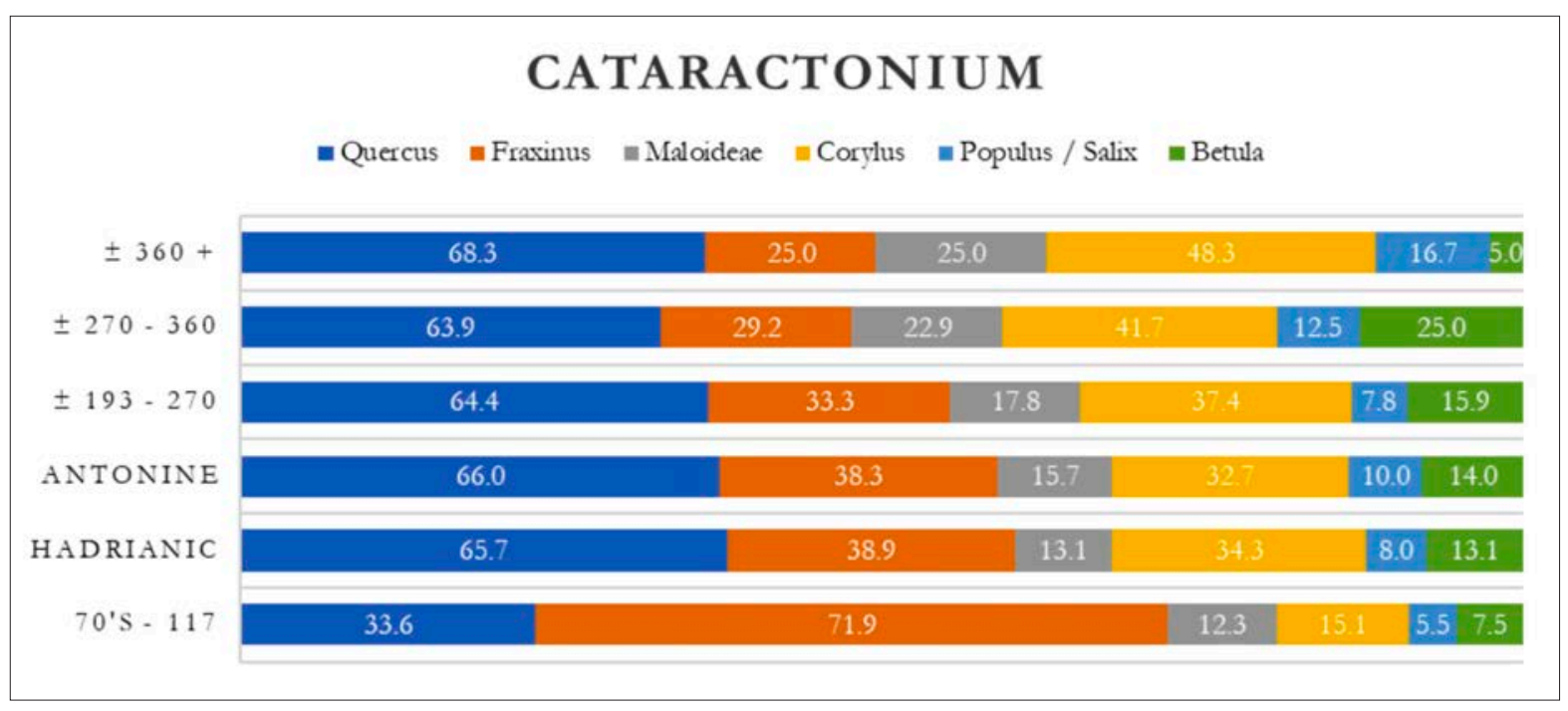

Fig. 5: Proportionate occurrence of the principal taxa by relative period at Cataractonium.

constant. With the departure of the army, yet still occupied, the settlement's boom declined and ratios approached normality, except for ash which was hypothesised as taking on a larger role in woodcraft. Similarly, the peak of pre-contact birch in the industrial quarter suggests it was either used for stoking furnaces in metalworking or it had a craft purpose of its own: the bark for dye and tanning and the resin for making glue. The ratios of the other taxa agree with the presumed "norm" in the periphery, because farmstead and domestic charcoal refuse mixed in form the adjoining comb-shaped enclosures and the early settlement core.

Alternatively, these fluctuations resulted from the shift between an input of wood obtained during land clearance - to meet an increased demand for pasture and arable land when the settlement grew or under pressure from Roman influences - and agricultural stability or stagnation. In the latter state (the periphery in the later period and the pre-contact road junction) oak dominates, with smaller inputs of the other principal taxa, because the wood usage for construction and fuel follows the traditional and sustainable practice. The artisans' need for hardwood fuel in the industrial quarter distorts the proportion of oak. With the waning of metalwork, reorganisation of the area and potential woodcraft, oak reduces towards the "norm" as do the other taxa, but ash increases. During the later conversion to enclosed "Romanised" plots, the indigenous use of oaken fuel and construction wood was in part subsumed by ash and hazel from managed copses with additional firewood sourced from hedges and land clearance. The ubiquity of heather, in particular in the periphery and core and at coeval settlements nearby (Zant 2013; Vyner 2001), Stanwick (van der Veen 2016b) and Late Iron Age pollen records from the region (Coggins 1985) corroborate the exploitation of wood from heaths and land clearances.

The hypothetical link between Roman influence and an increased deposition of ash charcoal finds substantiation in the vicus' record at Cataractonium: a higher ratio of ash than oak was preserved during its emergence and the establishment of the permanent fort. Once the military presence had diminished - in favour of a defence in depth along Hadrian's wall - and the vicus took on a more civilian character, ash diminished. Though good oaken timbers were reused, it dominated the record in the succeeding centuries because the constructions on this larger scale produced many scraps and flooded the available fuel supply. Ash however regrows faster and coppices easily into straight limbs. Perhaps when the Roman army arrived their large demand for woodwork stimulated management of ash copses and it substituted oak in the fashioning of sudes, the handles of pila and axes or in setting up encampments (Pratt 2017). The lowlying, riparian environment surrounding Scotch Corner and Cataractonium and their strategic situation meant the commission of indigenous woodcraft in ash may have been an expedient method for the rapid manufacture of 
sufficient equipment and logistical preparations to consolidate the occupation of northern England. Moreover, the frequent flares of insurgency kept demand up until the early 2nd Century. Although the Antonine disturbances with the Brigantes and the site's development into a defended vicus presumably affected wood exploitation at Cataractonium, the time scale between the respective phases in the third setting widens from a decennium to a century and samples no longer relate to the same generation of residents. The charcoal assemblage becomes too homogenous through frequent redeposition, whose social or economic cause are lost, to attempt further inferences on Roman logistics. Moreover, this homogeneity in the samples from the Hadrianic era through to Rome's abandonment of the region in the early 5 th Century, provides tentative support for the "normal" deposition of charcoal alluded to as representing farm life and domestic refuse in the Late Iron Age.

The ubiquity of charcoal from medium sized closed trees and scrub (Maloideae, Prunus sp., dogwood, guelder-rose and hazel in particular) suggests they abounded in the anthropogenic environment of ditches, hedges and trackways that enclosed the settled and rural land surrounding Scotch Corner, Bainesse and Cataractonium. They were a readily available source of tinder to meet the daily domestic requirement of firewood through pruning, deadwood collection and coppicing. A family for instance would not carry its fuel, every other day, over a long distance. Nor did they always, have access to "managed firewood" (sensu Dufraisse 2008: 209). If their fraction in the recovered charcoal record is primarily correlated to availability in the surrounding vegetation - cf. the principal of least effort in the collection of fuel (Rubiales 2011: 7) and the higher potential of deposition and preservation in the archaeological record - then the discrepancies between ash and oak in specific settlement phases implies a socio-economic or botanical cause. Because the ratios of ash and oak are interpreted in relation to the proportions of these other principal taxa, and they are mostly stable, the fluctuations are due to human circumstances on site, rather than botanic. Moreover, as a social filter presumably did not hamper ash exploitation before the arrival of Roman influence, because its pre-contact proportions, relative to the other taxa, are not distinctly low, the later increase may be interpreted as intentional economically, rather than culturally.

\section{WOOD COLLECTION EFFICIENCY}

We can however approach the fluctuations dendrologically: by contrasting the recovered fraction of charcoal of a taxon with its hypothetical proportion in the immediate vicinity. Relative to its occurrence in this anthropogenic landscape, the high proportion of heather could for instance evince land clearance to accommodate more livestock or till new plots (Lagerås and Bartholin 2003). Though ash and oak flourish in open woods, along boundaries and becks, their archaeological share exceeds their ubiquity in the on-site vegetation. This suggests additional ash and oak was brought in from beyond the customary wood foraging range. Interpretation of this "extra" distance is in relation to the range of daily firewood collection. Though the retrieval of scrub and hardwoods from the surrounding vegetation for fuel needed to be efficient, the wood used in the manufacture of tools and construction was a different resource category and followed economic, not domestic principles of efficiency (Dufraisse 2014). Craftspeople may therefore have acquired some of their wood from beyond the ordinary firewood collection range.

Because those people that lived inside the walled town were slightly more distant from the surrounding tree cover than those in the extramural town, contrasting both records could test whether distance was an important element in the acquisition of wood. Although the differences are slight (see fig. 6) more wood from hedges was preserved outside than inside the town wall. The discrepant proportion of birch, scots pine, wych elm and lime suggests intramural inhabitants may have imported some of their wood from beyond the immediate vicinity. Though not very conclusive, this dataset implies living within the town's wall affected acquisition of wood, but this may have been due to archaeologically invisible distinctions in the inhabitant's profession or class and the circumstance of the examined structures.

Wych elm was found in all three settings and though these fragments may have derived from opportunistic firewood collection, along nearby becks or the river Swale, it is not a common firewood. Primarily, because it takes many months to dry, due to its high water content, branches are not efficient kindling. Moreover, due to an interlocking grain, elm boughs and trunk wood are hard to split. Secondly, as the settled landscape of Scotch Corner and Cataractonium did not favour wych elm, it presumably was not a regularly encountered tree (Huntley 
On Contrasts in Charcoal Assemblage of a Late Iron Age and Romano-British Roadside Settlement

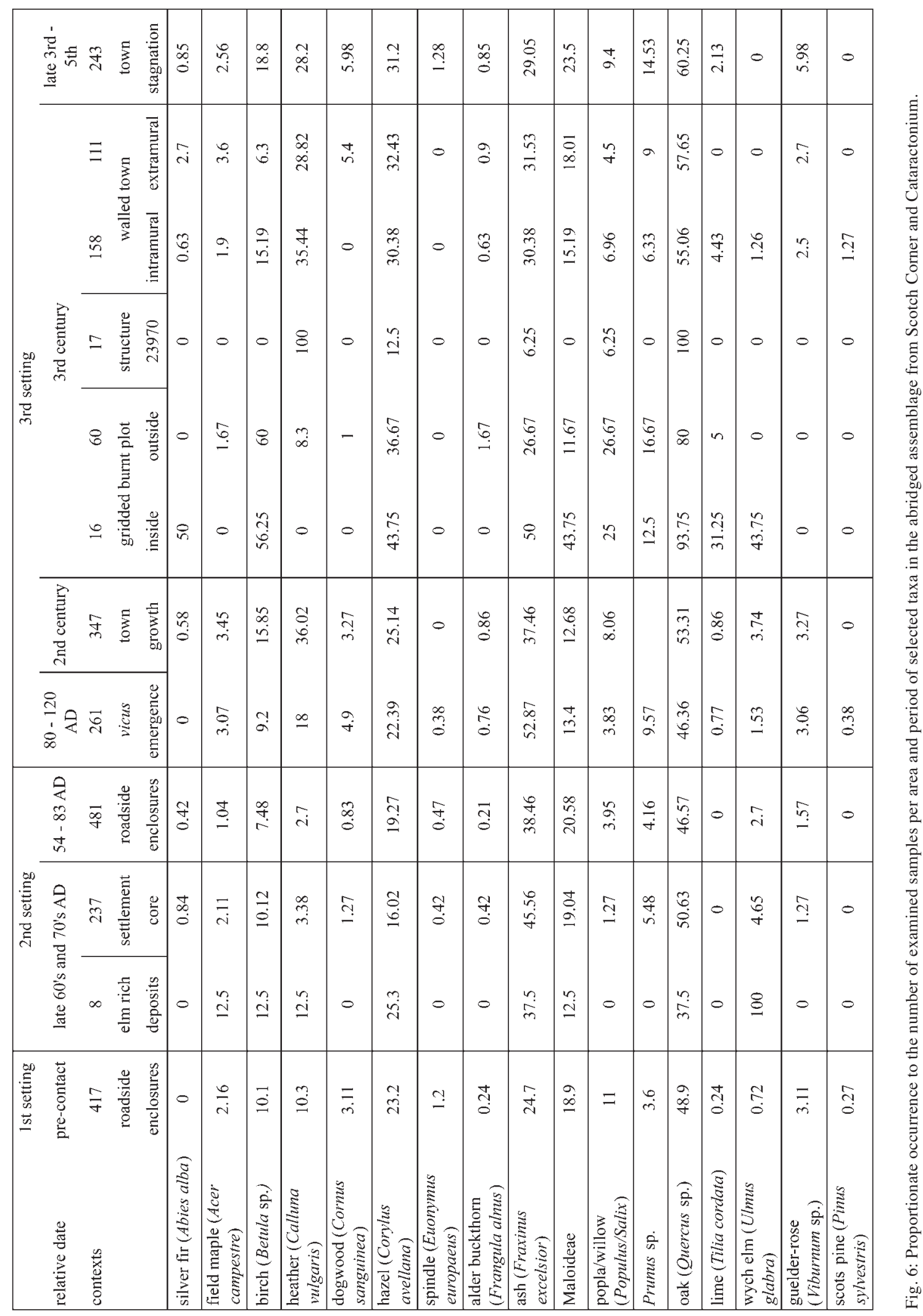


2010). Its wood, on the other hand, is well suited for the manufacture of furniture, wheels and handles for tools and for fashioning posts and stakes (Koot and Vermeeren 1993). The principal element for tentatively distinguishing between remains of spent fuel and worked wood however is find location and context (Dufraisse 2008; Campbell et al. 2011). Whilst the diffuse pre-contact occurrences of wych elm in the peripheral enclosures for instance are unclear, the concentration in the second setting (presented in the second column of fig. 6) probably derived from woodcraft. Approximately $37 \%$ of the 103.3 grams of charcoal found in a distinct cluster of seven pits and a stretch of a rectangular ditch, that enclosed half an acre on the outer side of the road junction, dating to the late 60 's and 70's AD, was wych elm. No signs of demolition or land clearance of indigenous structures was observed in the vicinity. I present three narratives, though there may be others. First, the elm was deposited around the time Vespasian became emperor and Agricola saw an end to strife between the Brigantes and Rome. Plausibly they represent the remains of part of an army's discarded equipment; burnt in situ on the side of the main road. Alternatively, the area served as a central paddock, subdivided into private and communal stalls with timber stockades that included wych elm joinery. When the community fell on hard times, Roman interests had moved onwards or they were momentarily beaten off, such remembrances of their occupation easily presented the locals with a few nights of easily collected dry firewood. A final option interprets the wych elm charcoal as a portion of spent bonfire fuel to celebrate an event in the 70 's AD which had accumulated in nearby open (sensu Jacomet 1989) archaeological features.

Wych elm also concentrates inside the timber building, that burnt down within the town, but not outside in the surrounding patch (see fig. 7 and the 7 th and 8th columns respectively of fig. 6). Interpretation as artefactual or structural remains is encouraged by a corresponding concentration of lime and silver fir charcoal. Though silver fir was imported and not primarily firewood, lime shared a prevalent place in mature forests with ash and oak. Considering this article interprets the discrepant ratios of ash and oak, in the era of Roman contact at the vicus and roadside settlements, as a sign that wood was brought from beyond the usual collection range, lime may have been included. Note however that birch does not share the same habitat preference and was brought from a different environment or through clearance.
Lime's diffuse occurrence in the assemblage overall, in contrast with other rarer dense woods such as field maple or alder buckthorn, implies the distinct concentration in the timber building is not as an infrequent component of the log pile. Because its straight grain was favoured by furniture makers, plausibly the lime fragments derived from such an artefact.

\section{A GRIDDED BURNT PATCH}

Because the burning down of the building in the plot that was excavated in $\mathrm{m}^{2}$ grid fashion presumably represents one distinct event, it facilitates spatial comparison of the sample composition temporally. An alignment of poplar or willow, yet a relative paucity elsewhere, for instance tentatively suggests hurdles existed for enclosing, or excluding animals adjacent to the timber house. The plot in question was not cleared before construction of a new building over the top. For this reason, I presume it feasible to compare the record inside the burned down timber structure with the charcoal scatter outside. Though the results instigate numerous other lines of discussion, the ratio between ash, hazel and oak corroborate with the previous observations. A higher proportion of ash, relative to its equal ratio with hazel in the town, was found inside rather than outside the structure. The proximity to artefactual or construction remains implied by this location could suggests some of the ash derived from the structure, particularly in joinery. Probably because hazel was a favoured wood in wattle and hurdles it is abundant both inside and outside the structure. The large volume of oak spread across the outside is probably linked to the interpretation given the abundance of birch - relative to its ratio in the town.

This 3rd Century conflagration layer was recognised in another section of the walled town, but further away from the trunk road and here discussed as timber structure 23970 (see fig. 6). Just 5 taxa were identified in its 17 $\mathrm{m}^{2}$ samples. The abundance of mature heather stems and broad oak fragments suggests a thatched roof set on oaken posts with wattle walls made of willow, hazel and ash. Although the absence of silver fir might seem striking, for comparison, it only occurred twice in the Roman period at the road junction and not at all in the earlier settlements. As both were in ovens, they presumably were discarded barrel or bucket staves brought from the continent and a chance find not readily expected everywhere regardless of the proximity of Roman trade and influence. 


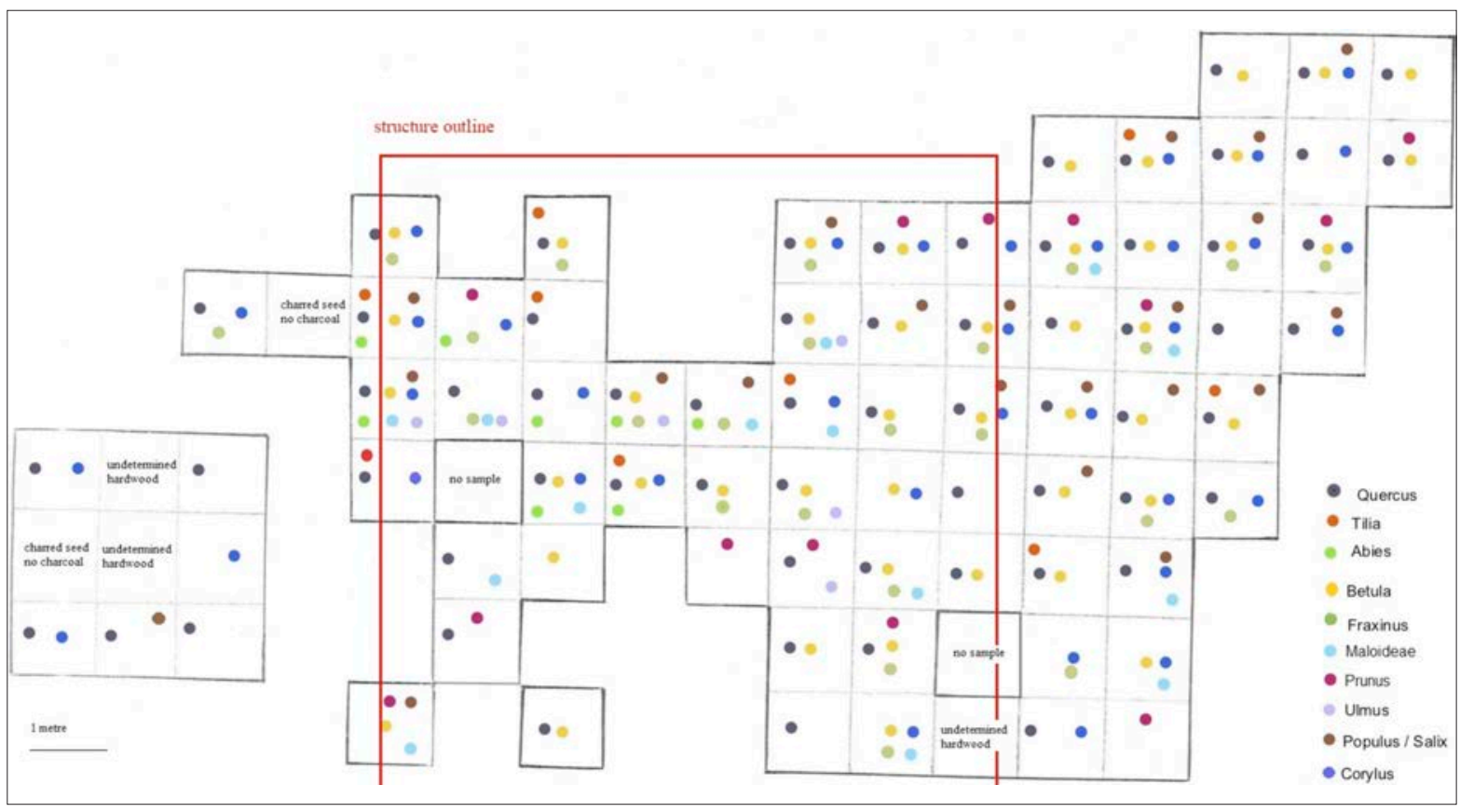

Fig. 7: Gridded charcoal distribution within the burnt patch at Cataractonium. The structure's outline, based on an alignment of substantial postholes, is marked.

Indeed, all throughout the establishment of the fortified camp and the vicus (approximately 80-120 AD), the absence of silver fir implies preservation potential and chance outweighs the degree of contact with the continent in its retrieval. It also occurred just twice in the 2 nd Century records and there in distinctly domestic sample contexts from within the defended vicus. Though this observation does not prove the silver fir in the large burnt spread was artefactual, it lends weight to interpretation of rare wood clusters inside the house as worked wood.

Not every incongruous proportion represents artefactual remains. The abundance in birch across the gridded burnt patch for instance is neither a sign of its use as rough flooring (Piggott 1953): the observable radii implied thin branches less than $8 \mathrm{~cm}$ in diameter, nor was it a favoured timber for construction. Supposing the ubiquity of heather in plot 23970 implies it was thus thatched and supported by an oak and ash frame with hazel and willow wattle, then the near absence of heather and the ubiquity of birch in the grid suggests it was supporting a sod roof there. Clumps of concreted vegetable matter and silt were found burnt with incalculable twigs, stems and imprints of leaf veins across the gridded spread, but neither these, nor birch were recognised in 23970. The spread of ash, elm and lime towards the north of the gridded structure, but not southwards, indicates these taxa supported a birch roof. In collapsing sideways, the structures' hazel and willow wattle burst out with its oaken timbers and populated $8 \mathrm{~m}^{2}$ without birch in the south. Though there is substantial evidence of burnt sods in the plant macrofossil assemblage, this supposition rests under the lack of comparison or reference of sod roofing in Britannia. Another narrative interprets the magnitude in birch branches as offcuts from the preparation of an "imported" log pile and represent a store of kindling. Because the proportion of birch site-wide closely matched that of the medium sized trees and shrubs in the vicus and later town - and was more readily available in wetter stands along the River Swale - possibly it was common firewood in the third setting. However, the discrepancy in proportion between the intra- and extramural samples, could suggest more birch was brought there, or sold, as firewood. A series of pits and ample bovine remains for instance may have been part of these activities (Ross in prep.). Though writing tablet 343 found at Vindolanda (http://vindolanda.csad.ox.ac.uk) refers to a large order of cured hides for the army, it contentiously does not indicate whether these were produced in Cataractonium or transported from 
there. The tablet nonetheless does suggest the town served as a depot for the army. The alder buckthorn fragments found here, at Bainesse and Scotch Corner however are more likely due to opportunistic collection of fuel when searching in the wider area, than for its yellow dye (Vajanto 2015). Likewise, the low, yet regular occurrence of privet and holly evinces opportunism, whilst gathering better firewood in the surrounding mature woodlands (Shackleton and Prins 1992).

\section{BAINESSE}

From the late Flavian occupation onwards, numerous non-indigenous enclosures emerged along Dere Street as a periphery to the main settlement at Bainesse (Speed and Holst 2019). The records of five distinct plots (see fig. 8) dating from the 2 nd to the 4th Century are discussed. Whilst Plot A had a timber building that fronted the road, plots $C, D$ and $E$ were further to the rear and backed onto a beck. Plot B was adjacent to A and part of the outspread network of bounded fields (Ross and Ross forthcoming). Though not temporally, they resemble the roadside periphery discussed in setting 1 geographically: on the main N-S artery, near a settlement core, engaged in a variety of occupations and set at the juxtaposition of the farm and urban environment. It might therefore be presumed that people there had access to the same vegetation as the inhabitants of the roadside settlements around Scotch Corner. Though not dominant, Maloideae, Prunus sp., dogwood and rose were proportionately common in the records and represent the same collection of deadwood as reflected on earlier. The smaller proportion of ash, birch and hazel in plots C, D and E relative to A suggest a different wood exploitation or settlement character. Besides the abundance of these taxa in plot $\mathrm{A}$, the distinct paucity of ash elsewhere contrasts well with the hypothesis that its over-representation at the junction and vicus reflects extensive coppicing and the addition of woodcraft remains in the era of direct contact with the Roman military. Moreover, these recent excavation and previous research in the area suggest roadside plots in the vicinity were involved in metalworking and an abundance of hammerscale and slag was found in plots A and B (Wilson 2002). The high proportion of birch, relative to the other two taxa, in plots A and B might therefore represent spent fuel from a forge. Alternatively, one might

\begin{tabular}{|c|c|c|c|c|c|c|}
\hline \multirow{3}{*}{ contexts } & \multicolumn{5}{|c|}{ 2nd Century AD } & \multirow{3}{*}{\begin{tabular}{|c} 
Neolithic \\
25 \\
pits
\end{tabular}} \\
\hline & 18 & 43 & 83 & 54 & 29 & \\
\hline & $\mathrm{A}$ & B & $\mathrm{C}$ & $\mathrm{D}$ & $\mathrm{E}$ & \\
\hline Ilex aquifolium & & & & & & 20 \\
\hline Ligustrum vulgare & & & 1.2 & & & 8 \\
\hline Lonicera periclymenum & & & & & 3.45 & \\
\hline Ulmus glabra & 5.5 & & & 1.85 & & \\
\hline Frangula alnus & & & 1.20 & & & \\
\hline Pinus sylvestris & 5.5 & & & 1.85 & & 4 \\
\hline Tilia cordata & 5.5 & & 3.61 & & & \\
\hline Viburnum & & 4.65 & 2.41 & 3.7 & 2.17 & \\
\hline Rosa & & & 4.82 & 11.1 & 3.45 & 8 \\
\hline Betula & 44.4 & 23.26 & 9.64 & 5.56 & 3.45 & \\
\hline Calluna vulgaris & & 20.93 & 4.82 & 18.5 & 55.2 & 12 \\
\hline Acer campestre & & & 7.23 & 13 & 6.9 & 4 \\
\hline Cornus & 5.5 & 7.05 & 7.84 & & 3.45 & \\
\hline Maloideae & 55.5 & 13.95 & 22.89 & 5.56 & 29 & 4 \\
\hline Populus / Salix & 27.78 & 13.95 & 6.02 & 22.2 & 10.3 & 24 \\
\hline Prunus & 5.5 & 13.95 & 9.64 & 11.1 & 6.9 & 32 \\
\hline Fraxinus excelsior & 44.44 & 13.95 & 18.07 & 9.26 & 10.3 & \\
\hline Corylus avellana & 60.6 & 12.98 & 27.71 & 31.5 & 27.2 & 64 \\
\hline Quercus & 83.33 & 48.38 & 34.94 & 44.4 & 48.3 & 36 \\
\hline
\end{tabular}

Fig. 8: Charcoal proportion from five Roman period plots and Neolithic pits around Bainesse. 
speculate this larger fraction of birch there, as well as in plot $\mathrm{C}$, reflects the increased potential for preservation of high calorific taxa and good construction wood in proximity to foci of domestic activities. Despite the absence of imported wood, the occurrence of a few of the rarer mature woodland taxa in plots $\mathrm{A}$ and $\mathrm{C}$ suggests the inhabitants consumed firewood transported from further afield.

The absence of heather in plot $\mathrm{A}$ and its relative paucity in plot $\mathrm{C}$ is conspicuous. Perhaps the similar record from inside the timber structure in the gridded patch, suggests heather was not commonly used as kindling in urban dwellings. Presumably heather's abundance in plots $\mathrm{B}, \mathrm{D}$ and $\mathrm{E}$, as well as most of the heather fragments recovered elsewhere in this assemblage, indicates its role in thatch and as cladding for hurdles or wattle. However, the longevity of plot A and the large fraction of hazel, oak and willow in its samples may be the result of momentary saturation of the available firewood with offcuts and demolition debris released during renovation. Tentatively a portion of the recovered field maple - perhaps birch as well in other contexts - in this assemblage derived from land clearance, or at least management of the primary regrowth.

Two social groups can be tentatively inferred in these peripheral plots. Though presumably the majority of the population on the outskirts of Bainesse followed the principal of least effort in the collection of their firewood, the greater variety in plot $\mathrm{C}$ suggests they obtained their firewood differently (Shackleton and Prins 1992). On the one hand, the occurrence of privet, alder buckthorn and lime suggest for instance that some wood was brought in from distant mature woodlands. The lower ratio of oak compared to ash, birch and hazel on the other hand implies more consumption of wood cut from nearby copses.

In comparing plot $\mathrm{D}$ and $\mathrm{E}$ with the reorganised plots in the former industrial quarter, a stark discrepancy in birch and hazel emerges between them and plot B, and a similarity in ash and heather that briefly sums up these particular ratios before examination of the Neolithic outlier.

First, more birch was found in B, than D and E. I postulate the large proportion of birch, relative to other locally more common taxa, implies a greater abundance in the archaeological environment - sensu preservation potential - than would have grown within comfortable carrying distance. Thus, I presume they are spent fuel brought in to supply the nearby metal workers.
Second, the slighter recovery of hazel in $\mathrm{B}$, than $\mathrm{D}$ and $E$ yet equal proportion of ash suggests B was more involved with the metalwork of its neighbours than the maintenance of hurdles or wattle structures used in animal husbandry and storage. This presumes access to copses was by incentive. Commoners did not exploit this resource for mere firewood if ample fuel was available from hedges and diffuse medium sized trees. Note in this instance the out of the ordinary volume of Prunus sp. in plot B may represent exploitation of a nearby border of blackthorn or cherry. The distinct proportion of honeysuckle (Lonicera periclymenum) in plot E also evinces that the surrounding scrub and tree cover was stripped for firewood. In this case the occurrence of a rare taxa is significant, regardless of its actual paucity - as this is mostly determined by the relationship between preservation potential and numeracy in the archaeological environment. In this instance therefore one might infer similarity in circumstance in plots A and D due to their shared, albeit minor, preservation of scots pine and wych elm. It also evokes the multiplicity of activities - and their subsequent waste - and debris in backyards or such rear plots, that include craft, horticulture and the keeping of livestock.

Third, I postulate most heather lay outside the customary firewood collection range and derived either from explicit gathering for use in construction or as a secondary boon from land clearance.

\section{A NEOLITHIC OUTLIER}

The absence of ash and birch in the Neolithic samples reinforces their anthropogenic place in the archaeological environment of the later roadside settlements. Though presumably the landscape was more wooded, the overall taxa composition of the tree cover was similar (Godwin 1968). Besides charcoal from shrubs and medium sized trees common to anthropogenic clearings (Buckland and Edwards 1984), the minor occurrence of maple and pine, as well as the profusion of holly, reiterates the principal of opportunism in firewood collection from nearby mature forests. Whether the wealth in holly implies people did not merely dispose of their spent fuel from hearths and common activities in pits, and a cultural filter predisposed particular taxa, is another issue. Tentatively the conspicuous dominance of hazel, Prunus sp. and willow reflects people's management of these taxa into borders for enclosing livestock or excluding wild animals and their reliable provision of pliable branches and kindling. 


\section{CONCLUSION}

This article examines the charcoal record from Late Iron Age and Roman period roadside settlements excavated during the A1 widening scheme between Leeming and Barton in north-eastern England. It explores whether the Roman occupation of the region (later 1st to early 5 th Century) affected the spectrum and proportions of taxa exploited for construction and as fuel compared to before contact. The results suggest that the "occupied" inhabitants continued their earlier Iron Age traditions with little archaeobotanically visible change. The Roman military and civilian officials did not impact a hypothetical "normal" range of collection for firewood, nor the choice of taxa. Discrepancies in the ratio of oak to other hardwoods are presumed to be the results of settlement development and an increased need for construction wood. Additional wood was therefore brought in from further away, and ash supplemented oak in construction and craftwork. A case is made for working wych elm, the use of birch in craftwork or as a particular fuel in metalworking and the recovery of lime and alder buckthorn as evidence for the exploitation of more distant mature forests. Though no morphological signs for coppicing were observed, the high ratios of ash, birch and hazel in the pre-contact and Roman samples suggest copses were managed to obtain a reliable and sustainable supply of wood. The ubiquity of mature heather stems and distinct proportions of field maple are interpreted as signs of land clearance activities. A landscape bounded by hedges, diffuse medium sized trees and wooded enclosure ditches is inferred from the abundance of poplar/willow, Maloideae and Prunus species. The much longer time scale involved in the exploitation of trees for fuel and construction wood, compared to arable regimes, meant that the incoming army and officials could not quickly alter the acquisition of these resources to meet their preference. As the 2 nd to 4 th Century record is numerically and taxonomically similar to the 1st Century - despite urban developments and the logistic pressures from supplying the military occupations - the newcomers probably maintained this inherited wooded and enclosed farm landscape and the indigenous wood exploitation practices. Because different time scales were examined: from settlement phases of approximately one generation, or less, to a century, the uncovered assemblage derives from various populations. Whilst some were roughly ancestral to the region, others moved there due to: conflict, military circumstance or pressures from urbanisation, roadside developments and the growth of the area into a logistical hub during the conquest and the subsequent occupation and defence of the northern frontier. As minimal differences in the charcoal assemblage were recognisable throughout the sampled periods, there was presumably limited acculturation of the indigenous. In sum, this report suggests the newcomers to the investigated area adopted the local practice of wood exploitation.

\section{REFERENCES}

AKERET, Ö.; MANT, J.; CARROTT, J.; JAQUES, D.; GARDNER, S.; UPEX, B. (2007): Biological remains, Pre-Construct Archaeology (PCA), An archaeological excavation at Faverdale East Business Park, Darlington, Unpublished PCA Post-excavation Assessment Report.

ARMIT, I. (2006): Anatomy of an Iron Age Roundhouse: The Cnip Wheelhouse Excavations, Lewis: The Society of Antiquaries of Scotland.

BISHOP, M. (2005): A New Flavian military Site at Roecliffe, North Yorkshire, Britannia 36, 135-223. DOI: https://doi.org/10.3815/000000005784016900

BRINDLE, T. (2016): Chapter 9: The North, The rural settlement of Roman Britain (A. Smith, M. Allen, T. Brindle, M. Fulford, eds.), Britannia Monograph Series 29, 308-329.

BUCKLAND, P.; EDWARDS, K. (1984): The longevity of pastoral episodes of clearance activity in pollen diagrams: the role of post-occupation grazing, Journal of Biogeography 11/3, 243-249.

DOI: https://doi.org/10.2307/2844643

CAMPBELL, G.; MOFFETT, L.; STRAKER, V. (2011): Environmental Archaeology. A Guide to the Theory and Practice of Methods, from Sampling and Recovery to Post-excavation (second edition). English Heritage.

CHALLINOR, D.; DRUCE D. (2013): Wood charcoal, Scots Dyke to Turnpike: he Archaeology of the A66, Greta Bridge to Scotch Corner (J. Zant, C. Howard-Davis, eds.), Lancaster, 116-124.

COGGINS, D. (1985): Settlement and farming in Upper Teesdale, Upland settlement in Britain: the second millennium $B C$ and after (D. Spratt, C. Burgess, eds.), B.A.R.-143, Oxford, 163-76.

CUFF, B. (2010): The auxilia in Roman Britain and the Two Germanies from Augustus to Caracalla: Family, Religion and Romanization, University of Toronto $\mathrm{PhD}$ thesis.

DUFRAISSE, A. (2008): Firewood management and woodland exploitation during the late Neolithic at Lac de Chalain (Jura, France), Veget Hist Archaeobot 17, 199-210. DOI: https://doi.org/10.1007/s00334-007-0098-6 
DUFRAISSE, A. (2014): Relation entre modes de collecte du bois de feu et état du milieu forestier: essai d'application du principe du moindre effort, Entre archéologie et écologie, une Préhistoire de tous les milieu. Mélanges offerts à Pierre Pétrequin. Environment, societés et archéologie 18, 493-504.

FERRIS, I. (2010): The beautiful rooms are empty: Excavations at Binchester Roman Fort, County Durham 1976-1981 and 1986-1991, Durham.

FITTS, R. L.; HASELGROVE, C.; LOWTHER, P. C.; TURNBULL, P. (1994): An Iron Age farmstead at Rock Castle, Gilling West, North Yorkshire, Durham Archaeological Journal 10, 13-42.

FITTS, R. L. (1999): Melsonby Revisited: Survey and Excavation 1992-95 at the Site of Discovery of the "Stanwick", North Yorkshire, Hoard of 1843. Durham Archaeological Journal 14-15, 1-52.

GODWIN, H. (1968): Studies of the Post-Glacial history of British vegetation, New Phytol. 67 (1), 95-107. DOI: https://doi.org/10.1111/j.1469-8137.1968.tb05458.x

HARDING, D. (2004) The Iron Age in Northern Britain: Celts and Romans, natives and invaders, London. DOI: https://doi.org/10.4324/9780203326107

HARDING, D. (2008): The Holme House villa, Roman Piercebridge: Excavations by D W Harding and Peter Scott 1969 1981 (H. Cool, D. Mason, eds.), The Architectural and Archaeological Society of Durham and Northumberland Research Report 7, 127-157.

HASELGROVE, C.; MOORE, T. (2016): Iron Age and Roman settlement in the Stanwick Environs, Cartimandua's capital? (C. Haselgrove, ed.), York, 358-374. DOI: https://doi.org/10.11141/RR175

HATHER, J. G. (2000): The Identification of the Northern European Woods: A Guide for Archaeologists and Conservators, London.

HUNTLEY, J. (1995): The carbonised plant remains, in P. Abramson et al., A Late Iron Age settlement at Scotch Corner, North Yorkshire, Durham Archaeological Journal 11, 7-18.

HUNTLEY, J. (2010): A review of wood and charcoal recovered from archaeological excavations in Northern England, English Heritage Research Department Report Series 68

JACOMET, S.; BROMBACHER C.; DICK, M. (1989): Archäobotanik am Zürichsee, Berichte Zürcher Denkmalpflege Monogr. 7.

JAQUES, D. et al. (2017): Animal and plant remains, A Roman roadside settlement at Healam Bridge (C: Ambrey, D. Fell, R. Fraser, S. Ross, G. Speed, P. N. Wood, eds.), NAA monograph 3: 216-242.

JONES, G. (1991): Numerical analysis in archaeobotany, Progress in Old World Palaeoethnobotany (W: Van Zeist, K. Wasylikowa, K. E. Behre, eds.), Berlin, 63-80.
KOOT C.; VERMEEREN C (1993): Natural wood resources and human demand: use of wood in Iron Age houses in the wetlands of Midden-Delfland, Analecta Praehistorica Leidensia 26, 99-110.

LAGERÅS P.; BARTHOLIN T. (2003): Fire and stone clearance in Iron Age agriculture: new insights inferred from the analysis of terrestrial macroscopic charcoal in clearance cairns in Hamneda, southern Sweden, Veget Hist Archaeobot 12, 83-92. DOI: https://doi.org/10.1007/s00334-003-0012-9

McCORMICK, M.; BÜNTEN, U.; CANE, M. A.; COOK, E. R. (2012): Climate change during and after the Roman Empire: reconstructing the past from scientific and historical evidence, Journal of Interdisciplinary History 43, 169-220. DOI: https://doi.org/10.1162/JINH_a_00379

MONCKTON,A. (2011): The regional setting and comparison with other sites, Two Iron Age 'aggregated' settlements in the environs of Leicester: Excavations at Beaumont Leys and Humberstone (J. Thomas, ed.), Leicester Archaeology Monograph 19, 133-136.

MOSKAL-DEL HOYO, M. (2011) The ubiquity correction as an alternative method for the quantification of charcoal, 5 th International meeting of Charcoal analysis (E. Badal, Y. Carrión, E. grau, M. Macías, M. Ntinou, eds.), Sagvntvm Extra 11, València, 35-36.

NAA (Northern Archaeological Associates) forthcoming: FELL D. (2019): Contact, Concord and Conquest. ROSS S.; ROSS C. (2020): Establishment, Consolidation and retreat.

PIGGOTT D. (1953): Milton Loch Craggnog 1. A native house of the 2nd century in Kirkcudbrightshire, Proceedings of the Society of Antiquaries of Scotland 87, 134-152

PRATT, J (2017): Management and use of Ash in Britain from the prehistoric to the present, Dieback of European Ash (R. Vasaitis, R. Enderle, eds.), Swedish University of Agricultural Sciences, 1-14.

RACKHAM, A.; GIORGI, J.; SMITH, W. (2013): Chapter 7 Palaeoenvironment and diet, The Roman roadside settlement and multi-period ritual complex at Nettleton and Rothwell, Lincolnshire vol. 1 (S. Willis, ed.), Kent, 301-346

RUBIALES, J. M.; HERNÁNDEZ, L.; ROMERO, F.; SANZ, C. (2011): The use of forest resources in central Iberia during the Late Iron Age. Insights from the wood charcoal analysis of Pinta, A Vaccaean oppidum, Journal of Archaeological Science 38, 1-10 DOI: https://doi.org/10.1016/j.jas.2010.07.004

SCHWEINGRUBER, F. H. (1990): Microscopic Wood Anatomy, 3rd Edition. Swiss Federal Institute for Forest, Snow and Landscape Research.

SHACKLETON, C.; PRINS, F. (1992): Charcoal analysis and the "principal of least effort" a conceptual model, Journal of Archaeological Science 19, 631-637. DOI: https://doi.org/10.1016/0305-4403(92)90033-Y 
SPEED, G.; HOLST, M. (2019): Death, Burial and Identity, Northern Archaeological Associates Monograph Series 4. DOI: https://doi.org/10.5284/1050910

VAJANTO K. (2015): Dyes and Dyeing methods in Late Iron Age Finland, PhD dissertation University of Helsinki

VAN DER VEEN, M. (2007): Formation processes of desiccated and carbonised plant remains - the identification of routine practice, Journal of Archaeological Science 34, 968-990. DOI: https://doi.org/10.1016/j.jas.2006.09.007

VAN DER VEEN, M. (2016a): Arable farming, horticulture and food: expansion, innovation and diversity in Roman Britain, The Oxford handbook of Roman Britain (M. Millett, L. Revell, A. Moore, eds.), Oxford.

VAN DER VEEN, M. (2016b): The arable economy, Cartimandua's capital? (C. Haselgrove, ed.), York, 304-321.
VYNER, B. (2001): Stainmore: the archaeology of a North Pennine pass, Tees Archaeol Monog Ser 1.

WIERINGA, J. (1958): Opmerkingen over het verband tussen de bodemgesteldheid en oudheidkundige veschijnselen naar aanleiding van de Nebokartering in Drente, Boor en Spade 9, 97-113.

WILLIAMS, D. (1973) Flotation at Siraf, Antiquity 47, 198-202. DOI: https://doi.org/10.1017/S0003598X00039132

WILSON, P. R. (2002): Cataractonium : Roman Catterick and its Hinterland. Excavations and Research, 1958-1997, Part 1, Council for British Archaeology Research Report 128.

ZANT, J.; HOWARD-DAVIES, C. (2013): Scots Dike to Turnpike: The Archaeology of the A66, Greta Bridge to Scotch Corner, Lancaster. 